\title{
Newton's religious screeds get online airing
}

\section{Geoff Brumfiel}

"Among the Beasts that represent Kingdoms I reccon the Dragon one. A Dragon signifies the person of a hostile King \& serpents according to their bigness the persons of other greater or lesser enemies." These words were penned not by an obscure mystic, but by a man many consider to be the father of modern science - Isaac Newton. They are part of the introduction to the 300,000-word interpretation of the book of Revelation that Newton wrote in the late seventeenth century. The work was published for the first time last month.

The writings reveal a religious fervour that until now has been seen only by scholars of science with access to archival manuscripts, according to Robert Iliffe, a science historian at Imperial College London. Iliffe directs the Newton Project, which posted the documents online on 15 July. "This is the first time that people can see what he really believed," he says.

Historians of science have long known of Newton's interest in religion and alchemy, but few realize the radical nature of his work, says Iliffe. "What he believed would have been hideous to virtually everybody in Oxford and Cambridge for decades to come," he says.

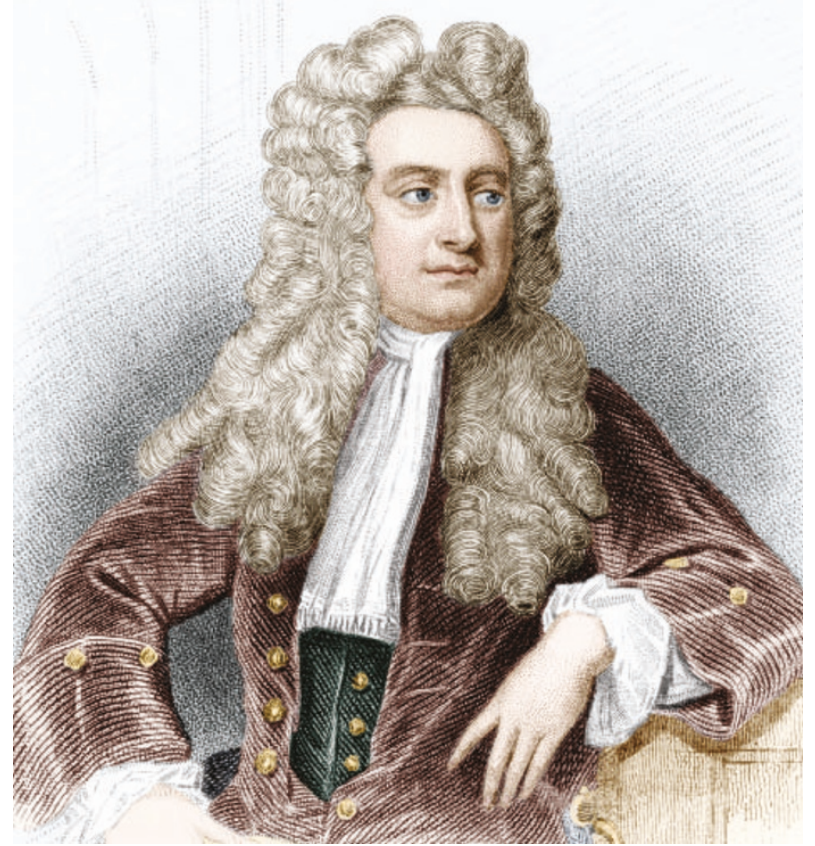

Revelation: the majority of Newton's writings were theological tracts.

Protestant parliament, before Charles II was restored to the throne.

But the vehemence of Newton's arguments pushed him well beyond the Anglican faith, to which he ostensibly belonged. "He believed that the Pope was the personification of the Antichrist here on Earth," Iliffe says.

Newton knew such beliefs lay outside the social mores of his peers, and there is no evidence that he ever published any of the writings now available online. Still, Iliffe says, Newton's religious writings constitute more than half of his entire written work.

In the past, many thought that Newton pursued religion only in his spare time, or that the majority of his religious work had been copied from others. But Iliffe claims that these writings show his theological work was carefully planned and often related to his work in mathematics and physics. For example, he sets up his text on the Apocalypse with mathematical formalism, outlining rules,

Among the unorthodoxideas in the text is a belief that Catholics, led by the Pope, are the false idolaters spoken of in the book of Revelation. Antagonism towards Catholics was not uncommon in Newton's period: during his lifetime England had experienced a bloody civil war that pitted Charles I, widely regarded as a Catholic sympathizer, against the mainly

\section{definitions and a proof of his beliefs.}

Ultimately, Newton's religion and science may have been tied together by belief in absolute truth. Newton used testable hypotheses to find truth in nature, and believed that his religious writings revealed the truth about God, says Iliffe.

www.newtonproject.ic.ac.uk

\section{Firm sets sights on gene silencing to protect vision}

\section{Erika Check, Washington}

A much-hyped technology known as RNA interference (RNAi) has moved a step closer to the clinic.

Biotechnology firm Acuity

Pharmaceuticals of Philadelphia,

Pennsylvania, asked for permission on 10 August to use the technique to treat a common cause of blindness. The clinical trial, if approved by the US Food and Drug Administration, would be the first of its kind.

RNAi, which uses short lengths of genetic material to selectively shut off genes, was demonstrated in human cells in 2001 and has yet to be tested in people. Some studies have raised concerns about just how selective the technique is, so observers say the filing is a landmark for the field but remain cautious.

"This is a significant milestone," says Greg Jensen, a biotechnology analyst at Ernst \& Young in Palo Alto, California. "Whether it will work out, or give us the first bad news about RNA interference, we don't know yet."
Acuity hopes to use a small interfering RNA to treat patients with wet age-related macular degeneration. The condition is caused by extended growth of blood vessels in the retina - a problem that Acuity thinks can be tackled by silencing the gene that triggers the growth. The company says that the condition affects more than

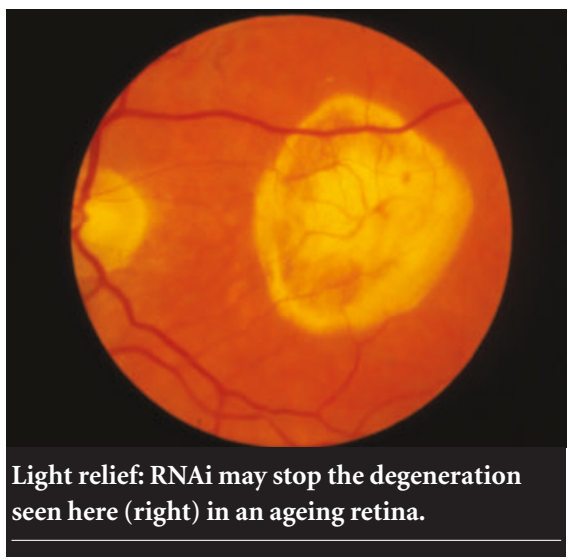

1.65 million people in the United States.

Dale Pfost, Acuity's chief executive, says his firm has applied for a patent on the RNA molecule involved, but the intellectualproperties issues are not straightforward. Rival firm Alnylam, based in Cambridge, Massachusetts, has already requested a patent on the method of RNA delivery that Acuity will use. Alnylam says it plans to begin its own clinical trials in macular degeneration next year.

Pfost is confident that Acuity's diseasespecific patent will be granted, but Alnylam begs to differ. "We're very pleased to see silencing RNAs entering the clinical stage," says John Maraganore, chief executive of Alnylam. "But at the end of the day, we believe that anybody developing RNAi therapies needs to talk to us." 